\title{
The Leptophlebiidae: Atalophlebiinae of New Caledonia (Ephemeroptera). Part VIII: systematics
}

\author{
Janice G. Peters ${ }^{1 *}$ and Nathalie Mary ${ }^{2 *}$ \\ 1 Entomology, College of Agriculture and Food Sciences, Florida A\&M University, Tallahassee, FL 32307, USA \\ 2 ETHYC'O, BP 140798, 98701 ARUE, Tahiti, Polynésie Française
}

Received 26 December 2015; Accepted 1 March 2016

\begin{abstract}
Neampia, a new genus of Atalophlebiinae (Leptophlebiidae) from New Caledonia, is described for the type species Neampia quaternaria new species, and five other new species. Of the three new subgenera established, three new species, Neampia quaternaria, Neampia inspina and Neampia richardi, belong to Neampia s.s. The second new subgenus, Goa, is monotypic and contains only the new species Neampia natans. The third new subgenus, Anodela, contains two new species, Neampia fluvialis and Neampia septentrionalis. Four of the new species are directly associated with nymphs by rearing, and two are associated by dissection of the developing genitalia in mature male nymphs.
\end{abstract}

Key words: New Caledonia / Atalophlebiinae (Leptophlebiidae) / new genus

\section{Introduction}

This paper is the eighth in a series on the systematics, phylogeny and biogeography of the Leptophlebiidae (Ephemeroptera) of New Caledonia. Part I of this series lists all localities (Peters et al., 1978). Other works are Peters and Peters (1980, 1981a, 1981b, 2000) and Peters et al. (1990, 1994). These publications and original localities and data of Starmühlner (1968) are available on Ephemeroptera Galactica (http://www.ephemeropteragalactica.com). For convenience, localities are repeated in Table Al and source of material for figures in Table A2. Neampia, a new genus with three subgenera (Neampia s.s., Goa and Anodela new subgenera) is described here. The genus is characterized by males with long, narrow penes with apical spines and females with an egg guide composed of an apical elongation of sternum 7 joined with a sclerotized anterior prolongation of sternum 8 . The nymphs are small with compact bodies, short antennae, narrow gills and apically divergent clypeal margins (Figs. 42, 43 and 48-50).

Methods are those described in previous sections. "Mature nymphs" refer to nymphs with well-developed wing pads - not necessarily last instar nymphs. In the male forelegs, the lengths of successive segments are compared

\footnotetext{
*Corresponding authors: janice.peters@famu.edu and nmary@free.fr
}

with the length of the tibia and expressed as a ratio; the length of the tibia is given in parentheses.

Repositories for the type specimens are abbreviated as: Florida A\&M University, Tallahassee, Florida, USA (FAMU), an affiliate of the Florida State Collection of Arthropods; Bernice P. Bishop Museum, Honolulu, Hawaii, USA (BPBM); National Museum of Natural History, Washington, DC, USA (NMNH); and the Musée cantonal de zoologie, Lausanne, Switzerland (MZL).

Neampia, new genus (Figs. 1-74)

N. genre 4: Mary and Archaimbault, 2012: 17, 46.

Imago. Length of male: body, 3.2-6.0 mm; forewings, 4.1-6.4 mm. Length of female: body $4.0-6.3 \mathrm{~mm}$; forewings, $5.2-7.2 \mathrm{~mm}$. Eyes of male separated on meson of head by distance greater than width of median ocellus to less than twice width of lateral ocellus, dorsally upper portion circular-shaped, lower portion of eye approximately equal to height of upper portion (Figs. 7-10); eyes of female separated on meson of head by length 3 to 4 times as great as maximum width of eye. Wings (Figs. 2-6): maximum width of forewings approximately half maximum length of forewings; vein Rs of forewings forked slightly less than to equal one-fourth distance from base to margin; vein MA forked approximately half distance from base to margin, fork symmetrical; vein $\mathrm{MP}_{2}$ attached at base to veins $\mathrm{MP}_{1}$ and $\mathrm{CuA}$ with a cross vein (Fig. 2), attachment of vein $\mathrm{MP}_{2}$ to $\mathrm{MP}_{1}$ slightly less than one-third of distance from base to margin, base of vein $\mathrm{MP}_{2}$ equidistant between veins $\mathrm{MP}_{1}$ and $\mathrm{CuA}$; 


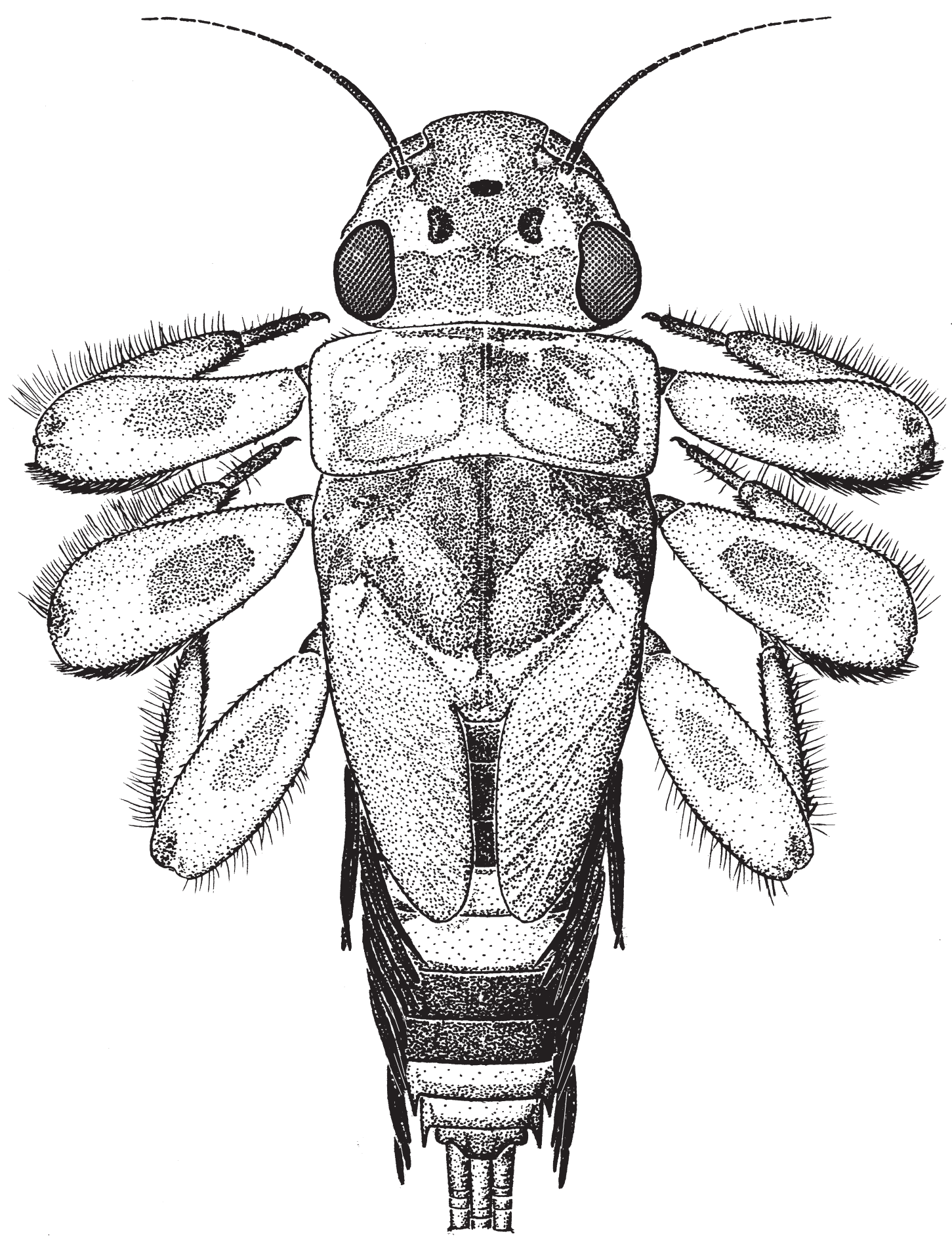

Fig. 1. Female nymph of Neampia (Goa) natans.

vein $\mathrm{ICu}_{1}$ attached to veins $\mathrm{CuA}$ and $\mathrm{CuP}$ with a cross vein (Fig. 2), a second intercalary weakly attached to $\mathrm{ICu}_{1}$; cross veins numerous. Coastal projection of hind wings rounded (Figs. 3-6), apex located half distance from base, apex sometimes curved over giving appearance of indentation; vein Sc ending past costal projection, approximately two-thirds distance from base of wing; vein MP not forked; apex of wings rounded; cross veins few. Legs: ratios of segments in male forelegs compared with length of tibia (1.4-2.1 mm): femur $0.60-0.80$; tarsal segments 1-5: 0.04-0.07, 0.30-0.37, $0.28-0.37,0.15-0.26,0.08-0.12$. Claws of a pair dissimilar, one apically hooked (Fig. 11) and other obtuse, padlike. Male genitalia (Figs. 17-33): segments 2 and 3 of forceps subequal in length, segment 2 of forceps one-seventh to one-fifth length of segment 1, apex of 


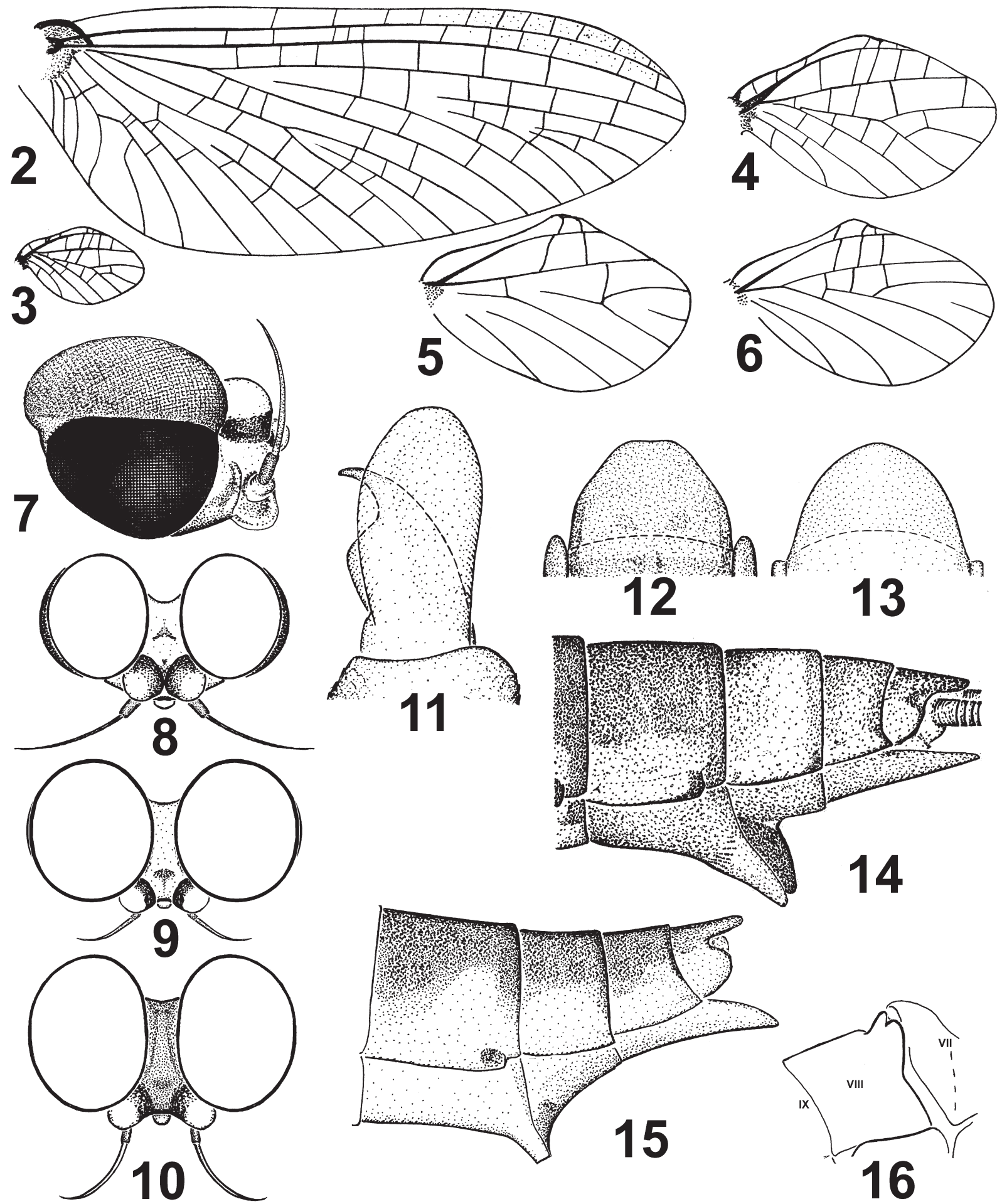

Figs. 2-16. Neampia male and female imagos: 2-4, 7-8, 11-12, 14, N. (Goa) natans; 5, 9, Neampia (s.s.) quaternaria; 10, N. (Anodela) fluvialis; 6, 15, N. (Anodela) septentrionalis; 13, 16, N. (Neampia s.s.) sp. Forewing (2); hind wing to scale (3); hind wing enlarged (4-6); male head, lateral view (7), dorsal view (8-10); male foreclaw (11); female ninth sternum (12-13); lateral view of posterior female abdominal segments (14-15); sternum VIII (16).

segment 3 blunt; base of forceps broad, its inner margin forming an angular bend near middle of forceps; length of styliger plate along median line one-half to two-thirds maximum width; apex of styliger plate shallowly to deeply cleft as in Figures 17, 24 and 29. Penes fused except at apex; narrow, tubular, apex of each penis lobe without apical spine (Figs. 21 and 22) or with small to large apical spine (Figs. 17-19 and 24-33); penes straight 

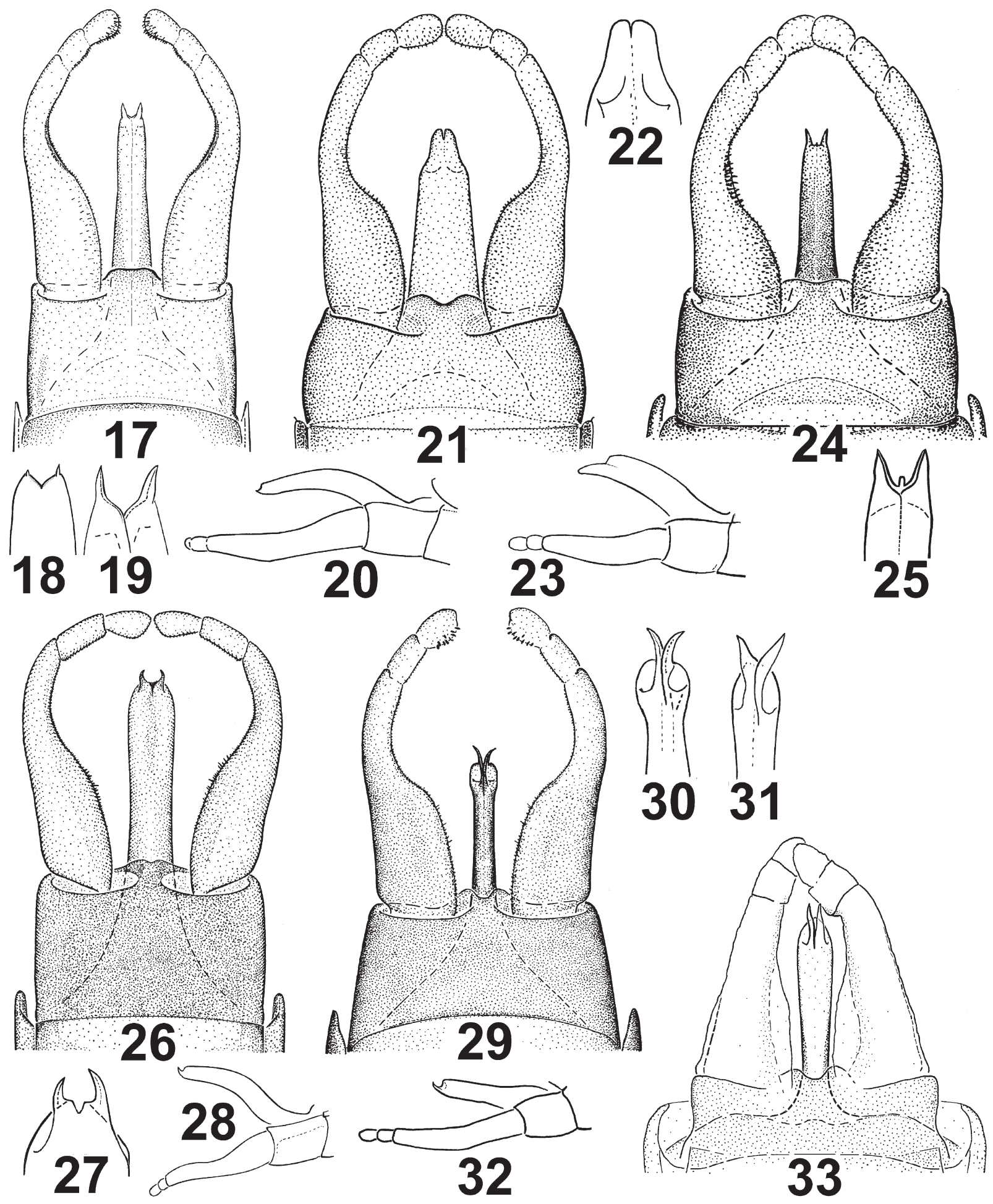

Figs. 17-33. Genitalia of male: 17-20, Neampia (s.s.) quaternaria; 21-23, N. (s.s.) inspina; 24-25, N. (s.s.) richardi; 26-28, N. (Goa) natans; 29-32, N. (Anodela) fluvialis; 33, N. (Anodela) septentrionalis. Genitalia, ventral view (17, 21, 24, 26, 29, 33), lateral view (20, 23, $28,30)$; detail, apex of penes, ventral (18-19, 25, 27, 31-32), dorsal (22). Figure 33 drawn from subimago.

(Fig. 32) to gently curved ventrally (Figs. 20 and 28). Posterior margin of female sternum 7 and anterior sternum 8 forming well-developed egg guide (Figs. 14-16). Ninth sternum of female entire, truncate (Fig. 12) or rounded (Fig. 13). Terminal filament slightly longer than cerci.

Egg (description based on $N$. (Goa) natans). Length and width $145 \times 70 \mu^{2}$; covered with circular structures, 

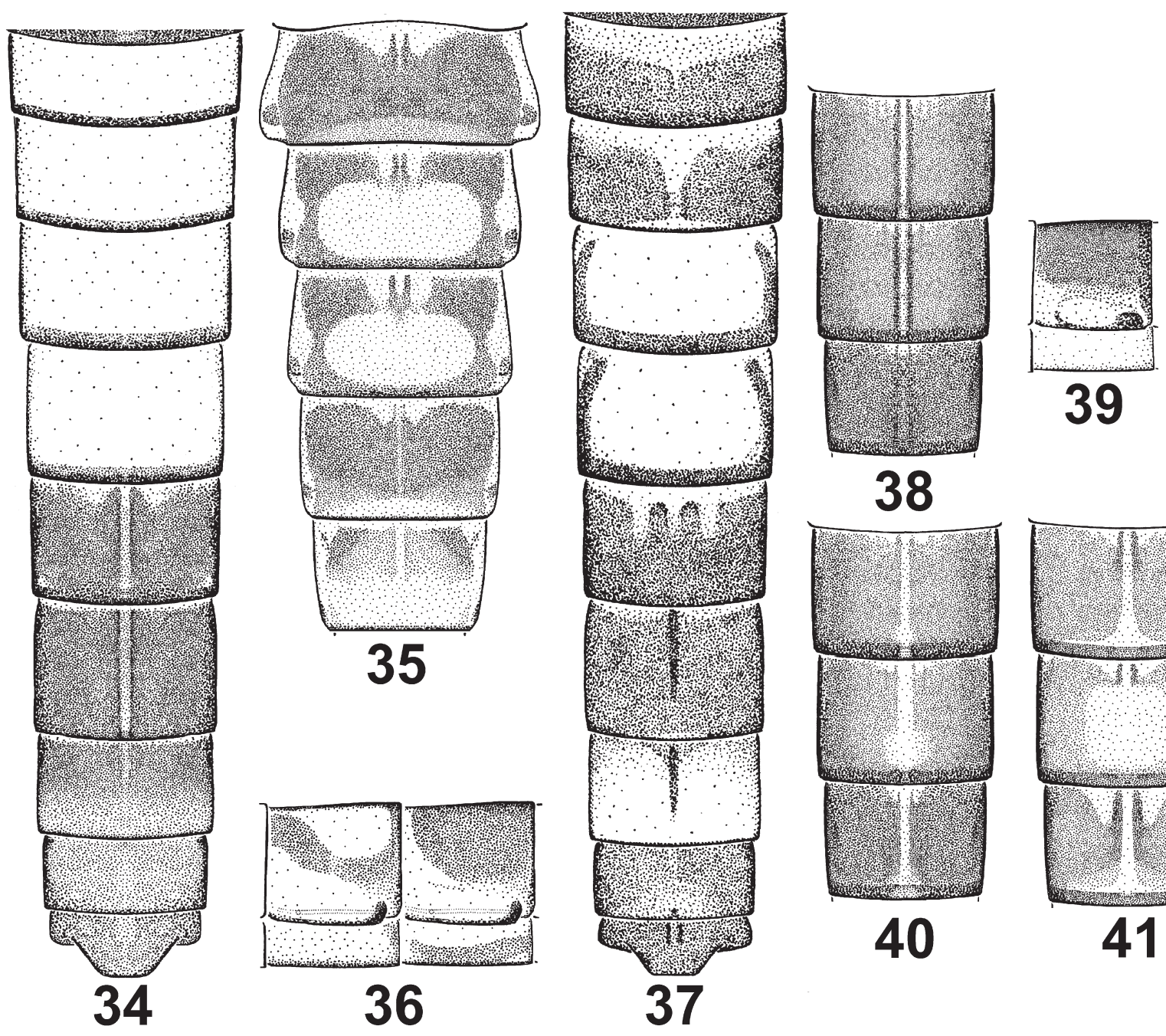

38

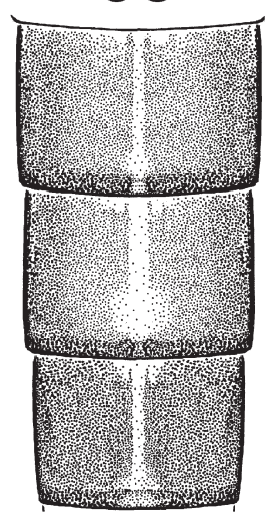

40

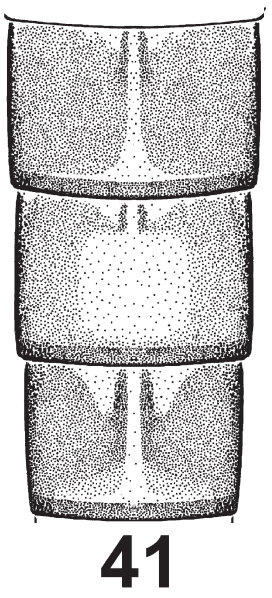

Figs. 34-41. Adult color patterns: 34-35, Neampia (s.s.) quaternaria; 36-37, N. (Goa) natans; 38-40, N. (Anodela) fluvialis; 41, N. (Anodela) septentrionalis. Male terga 2-9 (34, 37); 4-6 (38, 40-41); female subimago terga 3-7 (35); 36, lateral abdominal segments 5-6 (36), 5 (39).

each ringed with about 10 smaller attachment structures in floral pattern (Figs. 73 and 74).

Mature nymph. Head prognathous. Head and body flattened dorsoventrally (Fig. 42) to dorsum of head and body cylindrical, venter flattened (Fig. 1). Antennae 1.5 times maximum length of head. Mouthparts (Figs. 46-59): dorsal setae on labrum as in Figures 46-50, submedian and lateral areas of setae ventrally; anterior margin straight or with shallow median emargination, anteromedian emargination with five denticles, denticles blunt (Fig. 49) to rounded (Fig. 46); length of labrum along median line one-third to one-half maximum width. Clypeus as in Figures 48-50. Left mandible as in Figures 51, 53-55, lateral margin relatively straight (Fig. 55) or curved with shallow depression distal to curve. Lingua of hypopharynx with well-developed lateral processes, anterior margin cleft, apex of submedian lobes with rake-like process; superlinguae as in Figure 56, with row of setae along anterior margin, lateral margins blunt. Segment 2 of maxillary palpi subequal in length to segment 1; segment 3 of palpi more than two-thirds to slightly shorter than length of segment 2, triangular; $\mathrm{V}$-shaped ridge near ventral inner anterolateral margin of maxillae; setae on maxillae as in Figure 59. Labium as in Figure 57; segment 2 of palpi slightly shorter to equal length of segment 1; segment 3 of palpi three-fifths to fourfifths length of segment 2; paraglossae ventral to glossae. Legs (Figs. 60-70): maximum width of tibiae 2-3 times maximum width of tarsi, tibiae flattened to oval in crosssection (Figs. 63 and 64); outer margin of femora indented so tibiae can draw partially into femora (Figs. 60 and 62) or femora flattened, ventrally concave and enlarged (especially fore and mid femora) so tibiae can draw completely under femora (Figs. 1 and 61); apex of claws hooked and narrow, denticles on claws progressively larger apically (Figs. 65 and 66). Gills (Figs. 44 and 45): gills on segments 1-7 alike; gills deeply forked; dorsal and ventral portions of lamellae overlap, each portion long, smoothly tapered to apex; main trunk of tracheae forked near base of gills and each branch along the median line of lamellae 


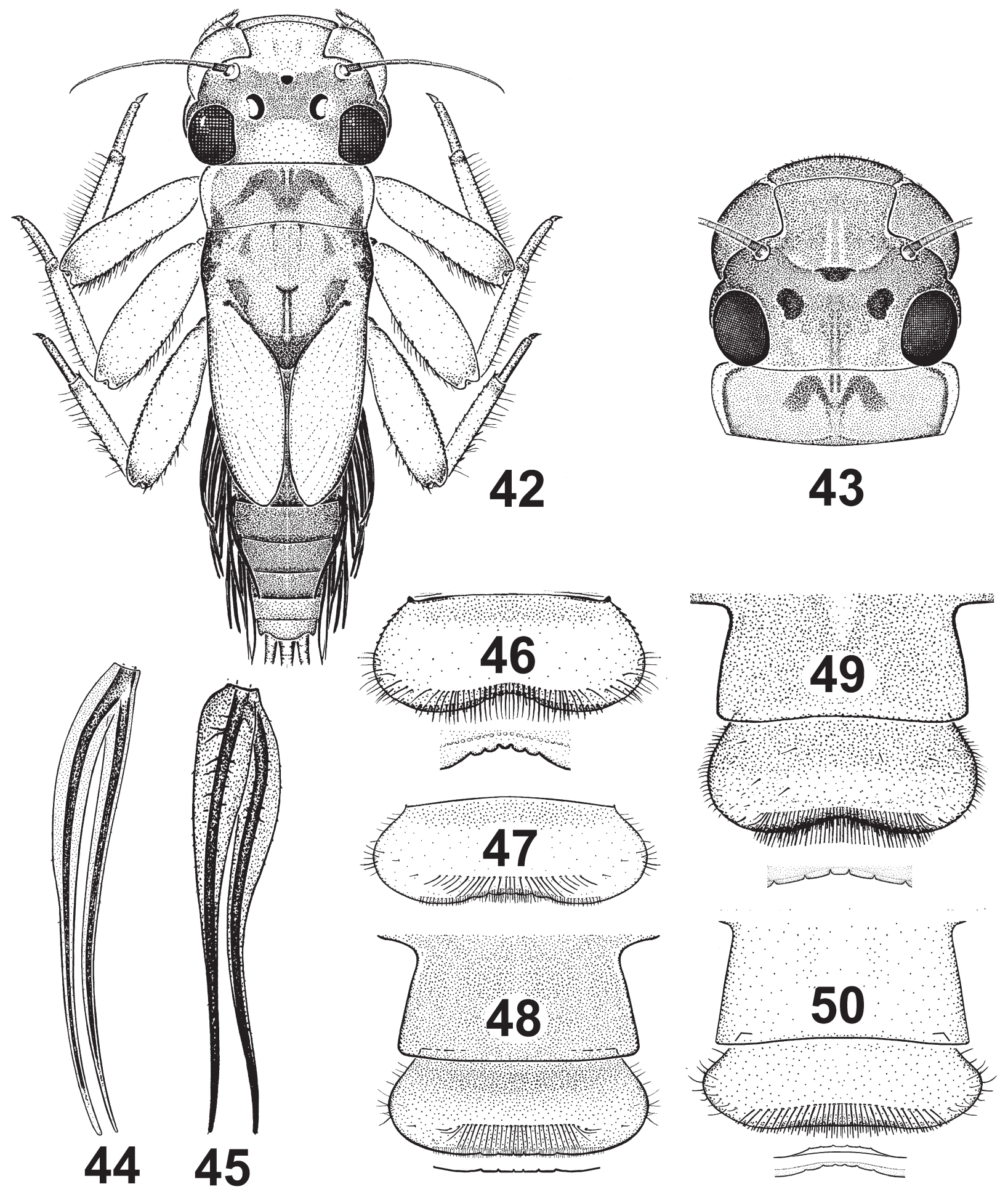

Figs. 42-50. Nymphs: 42, 50, Neampia (Anodela) fluvialis; 43, 48, Neampia (s.s.) richardi; 44, 46, Neampia (s.s.) quaternaria; 45, 49, N. (Goa) natans; 47, Neampia (s.s.) inspina. Full nymph, female (42); head and prothorax, female (43); gill 4 (44-45); labrum and clypeus (48-50); labrum (46-47). Detail of anteromedian emargination on 46, 48-50.

(Figs. 44 and 45); small unbranched tracheal branches occasionally present basally (Fig. 45); main trunk and branches pigmented, both portions of lamellae hyaline or grayish translucent. Posterolateral spines on abdominal segments 2 to $5-9$, spines progressively larger posteriorly, apex of posterolateral spines on segments 9 or $8-9$ indented and giving appearance of double spines. Terminal filament is slightly longer than cerci; caudal filaments with whorl of spines and setae of moderate length at articulations. 

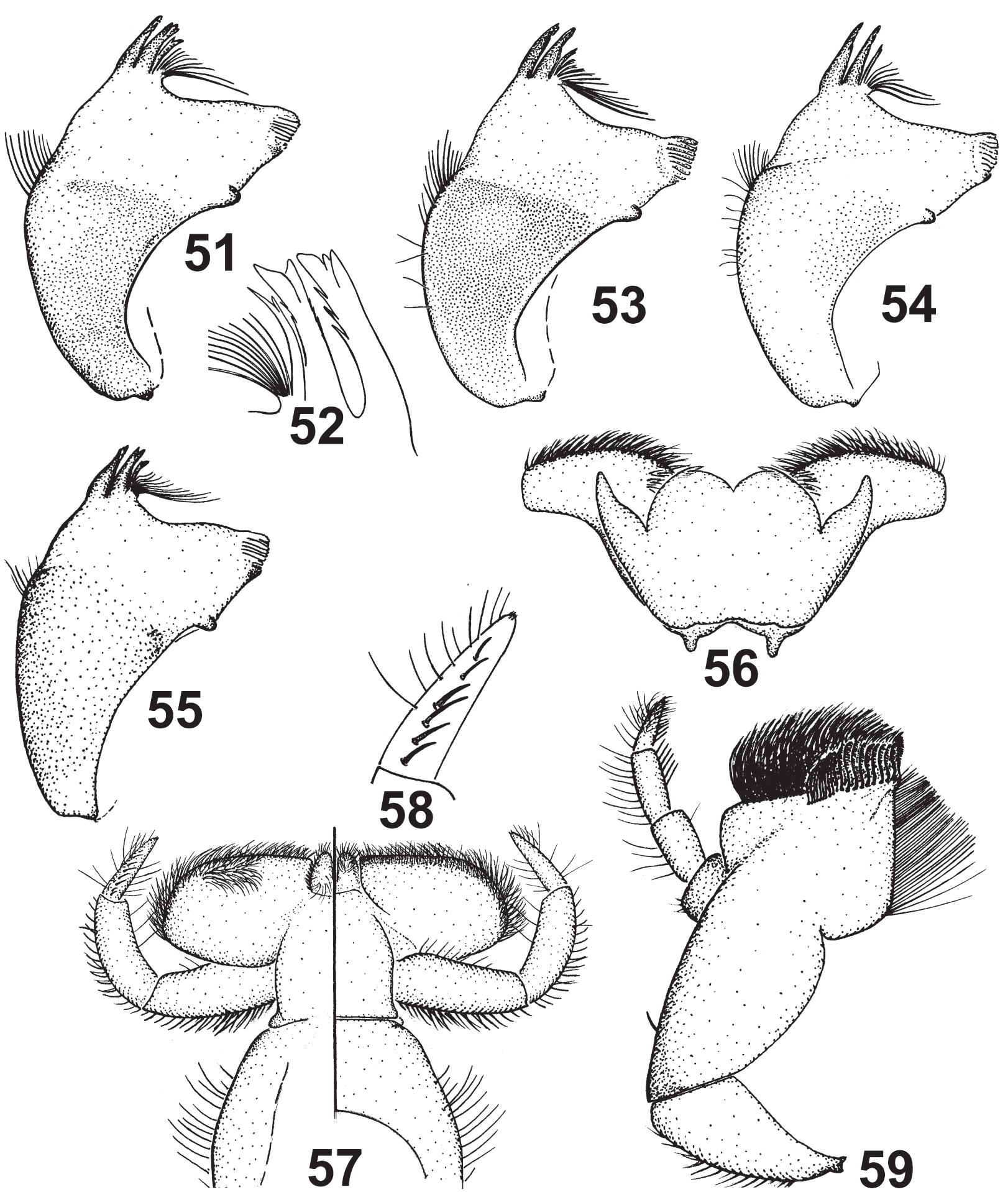

Figs. 51-59. Mouthparts of nymph: 51-52, Neampia (s.s.) quaternaria; 53, Neampia (s.s.) richardi; 54, N. (Anodela) fluvialis; 55-59, N. (Goa) natans. Left mandible (51, 53-55); right mandible, detail of incisors and base of prostheca (52); hypopharynx (56); labium (dorsal on left, ventral on right) with dorsal detail of third palpal segment (57-58); right maxilla, ventral (59).

Etymology. Neampia, based on the name Tribu de Neampia. Feminine.

Type species. Neampia (Neampia) quaternaria, new species.

Diagnosis. The following combination of characters will distinguish Neampia from all genera of the
Atalophlebiinae. In the imagos: (1) the $\mathrm{Cu}-\mathrm{A}$ area of forewings possesses two long intercalaries (Fig. 2); (2) vein MA of forewings is symmetrically forked near middle of wings; (3) length of vein Sc of hind wings is approximately two-thirds maximum length of hind wings (Figs. 3-6); (4) costal projection of hind wing is broadly rounded near 


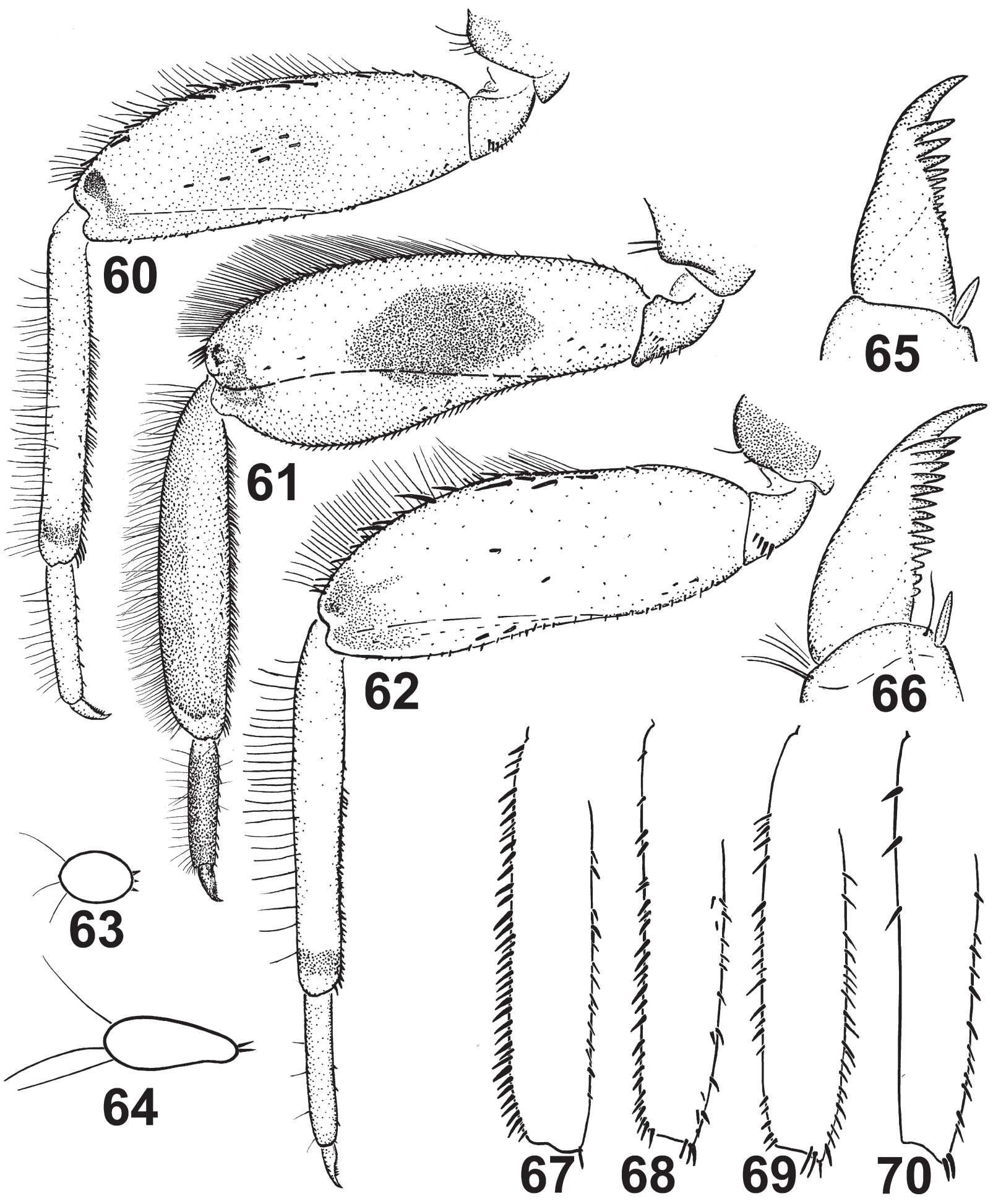

Figs. 60-70. Legs of nymph: 60, 63, 65, 67, Neampia (s.s.) quaternaria; 61, 64, 66, 69, N. (Goa) natans; 62, 70, N. (Anodela) fluvialis; 68 , N. (s.s.) inspina. Right foreleg (60-62); cross-section of tibia (63-64); foreclaw (65-66); outline of hind tibia with spine-like setae (67-70).

middle of anterior margin (Figs. 3-6); (5) claws of a pair are dissimilar; one is apically hooked and the other is obtuse, pad-like (Fig. 11); (6) penes are narrow, tubular and fused except at apex (Figs. 17-33) and each lobe usually possesses a small apical spine; and (7) female has a well-developed egg guide which is composed of the posterior projection of sternum 7 and a sclerotized anterior projection of sternum 8 (Figs. 14-16). In the nymph: (1) anterior margin of lingua of hypopharynx is cleft and inner apex of each submedian lobe has a rake-like 

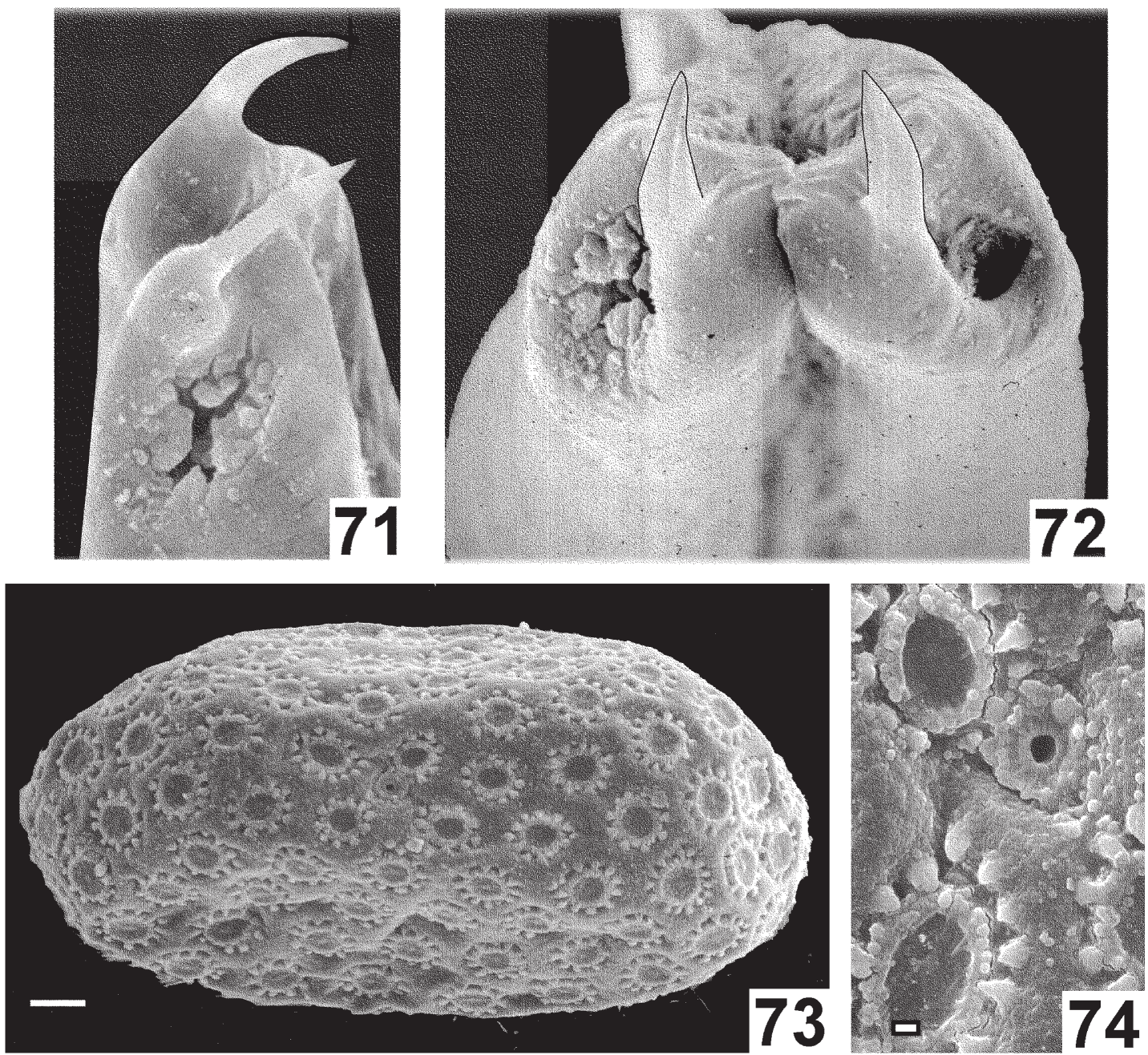

Figs. 71-74. SEM photographs of Neampia (Goa) natans: 71-72, apex of penes (outline of spines added in Fig. 72); 73, egg; 74, egg detail with micropyle. Scale bars: $73=10 \mu \mathrm{m}, 74=1 \mu \mathrm{m}$.

process; lateral margins of superlinguae are blunt (Fig. 56); (2) glossae of labium are dorsal to paraglossae (Fig. 57); (3) maximum length of segment 3 of labial palpi is three-fifths to four-fifths length of segment 2 (Fig. 59); (4) margins of clypeus are divergent apically and labrum is slightly broader than clypeus (Figs. 48-50); (5) anteromedian margin of labrum is shallowly concave or flattened with five round to flattened denticles (Figs. 46-50); (6) gills on abdominal segments 1-7 are similar, narrow, and divided to near base (Figs. 44 and 45); (7) outer margin of mandibles is gently curved (Fig. 55) or curved with a small indentation (Figs. 51, 53 and 54), and a tuft of setae occurs near middle of outer margin (Figs. 51 and 53-55); and (8) body is compact (Figs. 1 and 42).

Within New Caledonia, Neampia appears most closely related to Amoa Peters \& Peters from which it is distinguished in imagos by the narrow and tubular penes of the male and the well-developed egg guide of the female. The nymph can be distinguished by the divergent margins of the clypeus, the generally compact body shape and (in subgenus Goa) by the highly modified femora; also, the developing egg guide is usually visible in mature female nymphs. The short antennae ( $<2$ times length of head) of Neampia are a useful character for distinguishing mature nymphs, but antennae are longer in young nymphs.

In the key to Leptophlebiidae of New Zealand (Towns and Peters, 1996), adults of Neampia will key to Tepakia Towns \& Peters, from which they are distinguished by the dissimilar claws, an unforked MP vein in the hind wing, and the lack of setae on the openings of the penis lobes. The nymph is easily distinguished from Tepakia by its narrow gills and from New Zealand genera with narrow gills as follow: from Atalophlebioides Phillips, Neozephlebia Penniket, Austroclima Towns \& Peters and Mauiulus Towns \& Peters by the shallow anteromedian emargination of the labrum with subequal-sized denticles; and from Cryophlebia Towns \& Peters and Austronella Towns \& Peters by the presence of posterolateral projections on abdominal segments 2, 3, 4 or 5-9.

Biology. Mary and Archaimbault (2012) report this genus ("n. genre 4") as an indicator of good water quality, although there are probably differences in the tolerance 
of individual species. The species of the genus Neampia are generally found in low density (less than 200 individuals. $\mathrm{m}^{-2}$ ) in association with the following genera: Notachalcus Peters \& Peters, Lepeorus Peters et al., Paraluma Peters \& Peters, Simulacala Peters et al. and Celiphlebia Peters \& Peters. They occur in small-sized rivers and tributary streams in forested pristine environments. We found the nymphs mainly in streams draining ultramafic soils including: Kopéto massif, Thiébaghi massif, Southern Region (Yaté), watersheds of Thio, Dumbéa, Coulée; however, they can also occur in the Panié massif (Tao waterfall).

Key to species of Neampia, new genus

Imagos

1. Abdominal tergum 4 and most of tergum 5 dark brown (Figs. 38, 40 and 41); openings of penis lobes with acute ventroapical spines (Figs. 29-33) ........ 2

- Abdominal terga 4 and 5 pale (Figs. 34, 35 and 37); openings of penes with or without apical spines (Figs. 17-28)

2. Abdominal tergum 5 without large, pale median macula (Figs. 38 and 40)

Neampia (Anodela) fluvialis

- Abdominal tergum 5 with large, median, pale macula (Fig. 41) ............ Neampia (Anodela) septentrionalis

3. Abdominal terga $2-5$ of male hyaline except for narrow posterior band; terga 1 and 6-7 of male blackish to dark brown (Fig. 34)

. Neampia (s.s.) quaternaria

- Abdominal terga 1-3 and 6-7 of male blackish to dark brown (Fig. 37) ......................................... 4

4. Tarsal segment 4 of mid and hind legs dark brown; body size of male and female usually more than $5.0 \mathrm{~mm}$; apex of each penis lobe with an apical, recurved spine (Figs. 26-28, 71 and 72) ... Neampia (Goa) natans

- Tarsal segment 4 of mid and hind legs pale or pale brown apically; body size of male and female usually $<5.0 \mathrm{~mm}$; apex of each penis lobe of male genitalia without apical spine (Figs. 21 and 22) or with small apical spine (Figs. 17-19, 24 and 25)

5. Apex of each penis lobe without apical spine, penis openings dorsal (Figs. 21 and 22) so apex appears scoop-shaped in lateral view (Fig. 23) ....

........................................ Neampia (s.s.) inspina

- Apex of each penis lobe with a small apical spine, openings dorsoapical (Fig. 24)

Neampia (s.s.) richardi.

\section{Mature nymphs}

1. Fore and mid femora broadly expanded and paddlelike (Figs. 1 and 61); pronotum rectangular, broader than head or mesothorax (Fig. 1); dorsum of head and body somewhat cylindrical, venter flattened; outer margin of mandibles relatively straight (Fig. 55) .............................. Neampia (Goa) natans
- Fore and mid femora not paddle-like (Figs. 60 and 62); pronotum expanded anteriorly but not broader than head; head and body somewhat flattened dorsoventrally (Fig. 42); outer margin of mandibles with small depression distal to tuft of setae (Figs. 51, 53 and 54)

2. Color pattern mostly blackish brown on abdominal segments $4-5$, or with pale median area on tergum 5 (as in Figs. 38 and 40-42); outer margin of hind tibia with few $(<6)$ spine-like setae (Fig. 70) Neampia (Anodela) 3

- Color pattern pale on abdominal terga 4-5 as in Figs. 34, 35 and 37; outer margin of hind tibia with numerous ( $>15$ ) spine-like setae (Figs. 67 and 68) . Neampia (s.s.) 4

3. Abdominal tergum 5 with large pale, median macula (as in Fig. 41) .... Neampia (Anodela) septentrionalis

- Abdominal tergum 5 blackish brown, without large median pale macula (Fig. 42)

.................................. Neampia (Anodela) fluvialis

4. Abdominal terga $2-5$ of male nymphs pale (as in imago Fig. 34); anterior margin of labrum concave (Fig. 46); outer margin of hind tibia with $>27$ small, regular spine-like setae (Fig. 67) ... . Neampia (s.s.) quaternaria

- Male nymphs with pale color pattern on abdominal terga $4-5$ as in Figures 35 and 37; anterior margin of labrum weakly concave to straight (Figs. 47 and 48); outer margin of hind tibia with approximately 15-27 irregular spine-like setae .......................... 5

5. Clypeus, mandibles and most of head blackish (Figs. 43 and 48); body color highly contrasting between pale and dark areas; anterior margin of labrum straight (Fig. 48) ................. Neampia (s.s.) richardi

- Clypeus washed with brown, but not solidly colored as above; general body color light brown; anterior margin of labrum weakly concave (Fig. 47) Neampia (s.s.) inspina

Neampia sensu stricto, new subgenus (Figs. 5, 9, 17-25, 34, $35,43,44,46-48,51-53,60,63,67$ and 68)

Diagnosis: Imago. Apex of penis lobes of male genitalia without spines (Figs. 21 and 22) or with small spines (Figs. 17-19, 24 and 25); openings of penes dorsal or dorsoapical. Mature nymph. Head and body flattened dorsoventrally. Mouthparts: anteromedian emargination of labrum concave to straight, length of labrum less than one-half but greater than one-third width (Figs. 46-48); outer margin of mandible curved, with depression anterior to lateral setal tuft (Figs. 51 and 53). Foretibiae oval in cross-section (Fig. 63), outer margin of femora indented so tibiae can draw partially under femora (Fig. 60); outer margin of hind tibiae with heavy row of 15-40 spine-like setae and scattered hair-like setae (Figs. 67 and 68). Posterolateral spines on abdominal segments 3,4 or $5-9$.

Type species. Neampia (Neampia) quaternaria, new species.

Discussion. The characters above will distinguish the male imagos and nymphs of Neampia (s.s.) from those of 
the new subgenera Goa and Anodela. A single female subimago is designated as allotype of the type species Neampia (s.s.) quaternaria because the specimen is reared and intact hind tibiae are present on the exuviae to confirm the association. The apex of the 9 th sternum of this female is truncate, but it is rounded on smaller females from other localities, such as Neampia sp. (Fig. 13) collected with males of $N$. quaternaria at N50. This difference may be size-dependent rather than a character of species. All females of Neampia (s.s.) appear to have the same general color pattern (Fig. 35), and unassociated females cannot be placed to species. The egg guide of these females is similar to those illustrated (Figs. 14 and 15). The egg guide of subimagos is not as expanded as that of imagos. Female imagos and subimagos of Neampia (s.s.) spp. are recorded from N27, N35, N42, N50 and N54.

Neampia (Neampia) quaternaria, new species (Figs. 5, 9, 17-20, 34, 35, 44, 46, 51, 52, 60, 63, 65 and 67)

Male imago (in alcohol). Length: body, 3.6-6.0 mm; forewings, $5.0-6.4 \mathrm{~mm}$ (see discussion). Upper portion of eyes is reddish brown, the lower portion black. Head brown, carinae darker. Antennal scape and pedicel brown, flagellum paler. Thorax brown to dark brown, carinae darker, sutures paler, margins of prothorax and pleura washed with blackish brown. Coxae washed with dark brown, remainder of legs pale, except apices of femora with brownish marking and foretibiae tan. Wings (Fig. 5): longitudinal veins of fore and hind wings light brown; membrane of fore and hind wings hyaline, except apical third of cells $\mathrm{C}$ and $\mathrm{Sc}$ of forewings translucent. Abdomen: segments 1 and 6-10 opaque, segments 2-5 hyaline, washed with light brown; tergum 1 uniformly blackish brown, margins darker except near the anteromedian margin, terga 1-9 with darker brown band on posterior margin; terga 6 and 7 heavily washed with blackish brown (Fig. 34) fading to lighter brown on terga 8 and 9; spiracles dark brown, tracheae washed lightly with dark brown; sternum 2 to posterior of sternum 6 pale, sterna 1 and 7-9 light brown. Genitalia (Fig. 17): brown, apical half of forceps paler; penes with small apical spines. Caudal filaments pale.

Male subimago (in alcohol). As in male imago, except for usual developmental differences; wing membrane tan.

Female imago. Unknown.

Female subimago (in alcohol). Length: body, $5.4 \mathrm{~mm}$; forewings, $6.2 \mathrm{~mm}$. Eyes black. Head light brown, carinae darker, washed with scattered blackish markings, sutures lighter. Antennal scape and pedicel dark brown, flagellum (broken off and missing) presumably paler as in male. Thorax: dark brown, carinae and median longitudinal suture darker, sutures paler, carinae of pleura and pronotum extensively washed with black. Markings of legs as in male imago, except base color of legs light brown. Wings: color and marks as in male imago, except longitudinal veins of fore and hind wings darker brown and membrane light tan. Abdomen: light brown, terga 2-6 with dark brown, posterior band on each tergum, tergum 1 uniformly washed with dark brown, tergum 10 uniformly washed with brown, terga 3-7 with color pattern as in
Fig. 35; spiracles dark brown, tracheae hyaline; sterna 2-6 with light brown, lateral stripes, sterna 8 and 9 uniformly washed with darker brown; egg guide weakly developed, washed with blackish brown. Caudal filaments light brown, paler at base, articulations pale.

Mature nymph (in alcohol). Head: light brown, washed with brown anterior to eyes and between ocelli, clypeus and area anterior to median ocellus pale. Labrum with concave emargination and five small, rounded denticles (Fig. 46). Thorax brown, venter lighter, lateral areas of mesonotum, median longitudinal suture, posterior portion of scutellum and areas around forewing pads washed heavily with darker blackish brown; pronotum with submedian transverse bars and lateral margins darker brown. Legs: pale; mid and hind coxae with brown macula; apex of femora with small dark brown macula; tarsi darker brown; outer margin of hind tibia with row of 27-40 closely spaced, small, spine-like setae (Fig. 67). Abdomen: color and marks as in male and female imagos. Gills (Fig. 44): membrane hyaline, tracheae black. Caudal filaments pale.

Material. Holotype male imago, No. N35; allotype female subimago, No. N21; paratypes: one nymph, two males, No. N13; four nymphs, No. N14; nine nymphs, three male subimagos, No. N21; one nymph, one male, No. N25; three nymphs, No. N34; two nymphs, one male, No. N35; two nymphs, one male subimago, No. N37; eight nymphs, one male, No. N42; six nymphs, No. N46; three nymphs, seven males, No. N50; four nymphs, one male, No. N51; one nymph, No. N52; 11 nymphs, one male, one male subimago, No. N53; five nymphs, one male, No. N54. All types are in alcohol. Association of the nymphs and adults is by rearing. Types are deposited in the following collections: holotype, allotype, six male, three male subimaginal and 23 nymphal paratypes at FAMU; four male, two male subimaginal and 13 nymphal paratypes at MZL, three male and 12 nymphal paratypes each at NMNH and BPBM. Additional specimens were collected by N. Mary from Pouembout $0\left(21^{\circ} 0^{\prime} \mathrm{S}\right.$; $\left.165^{\circ} 07.9^{\prime} \mathrm{E}, 260 \mathrm{~m}\right)$ and Tiwaka 5 (20 $59^{\prime} \mathrm{S}$; $\left.165^{\circ} 01^{\prime} \mathrm{E}\right)$. Other specimens from FNK4, FNK5, FNK37, FNK47, FNK52, FNK62, FNK66, FNK79 and FNK105 may represent minor variants of this species.

Etymology. Quaternarius, L., meaning consisting of four, in reference to pale abdominal color pattern on terga 2-5 of males.

Diagnosis. Neampia (s.s.) quaternaria can be distinguished from the remaining species of Neampia (s.s.) by the following combination of characters. In the imago: (1) abdominal terga 1 and 6-10 of male are opaque, dark brown to lighter brown posteriorly, and terga 2-5 are hyaline, washed with light brown (Fig. 34); and (2) apex of each penis lobe has a small apical spine and the openings of penes are dorsoapical (Figs. 17-19). In the nymph: (1) abdominal terga 1 and 6-10 of the male are dark brown and terga $2-5$ are pale (as in Fig. 34); (2) anteromedian emargination of the labrum is concave; (3) clypeus is pale; and (4) outer margin of hind tibia possesses a row of closely spaced, small, spine-like setae (Fig. 67). 
Discussion. The size range given for the males includes two specimens from N37, a small dark brown male subimago (body length $3.6 \mathrm{~mm}$ ) and a large male imago (body length $6.0 \mathrm{~mm}$, wing $6.4 \mathrm{~mm}$ ). For all other material, the body size of males ranges from 4.0 to $5.0 \mathrm{~mm}$. Specimens from the southern serpentine area are small and generally darker in color at localities N53 and N50, but slightly lighter at N51 (darkest on tergum 6 and apical half of tergum 7 and slightly paler on terga 8-9); at N54, the pattern is lighter overall and the blackish wash on tergum 6 may be less intense than that illustrated. The abdominal color pattern of female nymphs is variable throughout the range. Posterolateral projections always occur on terga 5-9, but smaller posterolateral projections on terga 3-4 or 4 may also be present. This character, like the number of spine-like setae on the hind tibiae, can vary in individuals between the left and right side of the body. The single female subimago assigned to this species is discussed under the subgenus.

Biology. Neampia (s.s.) quaternaria occurs throughout New Caledonia and was found in small streams to large rivers at altitudes of 6-458 $\mathrm{m}$ and water temperatures of $16.5-23^{\circ} \mathrm{C}$, but were most abundant at temperatures of $18-20.5^{\circ} \mathrm{C}$. Nymphs were found under small rocks along the river banks in slow moving water. Subimagos were collected at light traps.

Neampia (Neampia) inspina, new species (Figs. 21-23, 47 and 68)

Male imago (in alcohol). Length: body, $4.0-4.8 \mathrm{~mm}$; forewings, 4.8-5.2 $\mathrm{mm}$. Upper portion of eyes reddish brown, lower portion black. Head dark brown, carinae darker. Antennal scape and pedicel dark brown, flagellum light brown. Thorax dark brown, carinae darker, sutures paler, carinae of pleura and pronotum washed heavily with black. Coxae washed with brown, forefemora light brown, remainder of legs pale with apical margins of foretibiae and femora of all legs with brownish markings, apex of tarsal segments brownish. Wings: longitudinal veins light brown basally, slightly darker in apical fourth of cells $\mathrm{C}, \mathrm{Sc}$, and R1 of forewings; membrane of fore and hind wings hyaline, except base of fore and hind wings brown, cells $\mathrm{C}$ and $\mathrm{Sc}$ of forewings translucent. Abdomen: light brown, terga 1-9 with dark brown, wide, transverse band on posterior margin of each tergum, tergum 1 uniformly washed with dark brown, terga 2 and 3 washed heavily with dark brown except for narrow median area and lateral margins, terga 4 and 5 pale except for enlarged posterolateral blackish brown maculae above spiracles; terga 6-10 washed with dark brown similar to Figure 34; spiracles dark brown, tracheae washed lightly with dark brown; sterna 1-6 light brown, sterna 7-9 lightly washed with brown. Genitalia (Figs. 21-23): brown, apical half of forceps and penes paler; penes with dorsal openings, but without spines. Caudal filaments pale with dark articulations in basal half.

Male subimago. Unknown.

Female imago and subimago. Unknown.

Mature nymph (in alcohol). Head: light brown, washed with brown except on vertex and anterior to median ocellus. Labrum with shallow concave emargination and small rounded denticles (Fig. 47). Thorax: brown, venter lighter, lateral areas of mesonotum and areas around forewing pads washed with darker blackish brown, scutellum mostly pale, blackish at apex, pronotum with submedian brown transverse bars. Legs: pale; mid and hind coxae with brown macula; apex of femora with small, blackish macula; tarsi dark brown; hind tibia with $15-27$ posterior spine-like setae (Fig. 68). Abdomen: color and marks as in male imagos; posterolateral projections on abdominal segments 2, 3 or 4-9. Gills: membrane hyaline, tracheae black. Caudal filaments pale brown.

Material. Holotype male imago, No. N54; paratypes: one nymph, No. N13; two nymphs, No. N15; one nymph, two males, No. N35; six nymphs, No. N53; eight nymphs, one male, No. N54. All types are in alcohol. Association of the nymphs and adults is by dissection of developing male genitalia from nymphs from the same locality. Types are deposited in the following collections: holotype, one male and eight nymphal paratypes at FAMU; one male and four nymphal paratypes each at MZL and NMNH, and two nymphal paratypes at BPBM. Other specimens appearing to belong to this species include nymphs from N27 and FNK53.

Etymology. in-, L., meaning without; spina, L., meaning spine.

Diagnosis. Neampia (s.s.) inspina can be distinguished from the remaining species of Neampia (s.s.) by the following combination of characters. In the imago: (1) abdominal terga 1-3 and 6-10 of male are dark brown and terga 4 and 5 are pale; and (2) apex of each penis lobe does not have an apical spine and the openings are dorsal (Figs. 21-23). In the nymph: (1) abdominal terga 1-3 and 6-10 of male are dark brown and terga 4 and 5 are pale; (2) anteromedian margin of the labrum is shallowly concave with rounded denticles (Fig. 47); (3) clypeus is light brown or darker brown with contrasting darker markings; and (4) posterior margin of hind tibia possesses 15-27 spine-like setae (Fig. 68).

Discussion. All imagos are from a single locality on two dates (N35, N54) and associated nymphs have a light brown clypeus with few markings. The clypeus on associated nymphs from N53 is also light brown but with darker brown apical and lateral markings. The color pattern of male imagos is similar to that of $N$. richardi $\mathrm{n}$. sp. from which it is distinguished by the lack of spines on the penes.

Biology. Neampia (s.s.) inspina has been collected on the West Coast from Nondoué to Païta and from tributaries of the Rivière Bleue. The species is found in large streams at $31-122 \mathrm{~m}$ with water temperatures of $18-20.5^{\circ} \mathrm{C}$. Adults were collected as subimagos at light traps and kept until they transformed to imagos.

Neampia (Neampia) richardi, new species (Figs. 24, 25, 43, 48 and 53)

Male imago (in alcohol). Length: body, $4.0-4.5 \mathrm{~mm}$; forewings, $4.5-4.8 \mathrm{~mm}$. Upper portion of eyes reddish brown, lower portion black. Head dark brown, carinae darker, sutures paler, anterior margin around base of 
antennae blackish brown. Antennal scape and pedicel dark brown, flagellum paler. Thorax dark brown, carinae darker, sutures paler; carinae of pleura and pronotum washed heavily with black. Coxae washed with dark brown, remainder of legs pale, except apex of femora and foretibiae dark brown. Wings: longitudinal veins of fore and hind wings light brown, cross veins hyaline; membrane of fore and hind wings hyaline, except apical third of cells $\mathrm{C}$ and $\mathrm{Sc}$ of forewings translucent. Abdomen: light brown, terga 1-9 with dark brown, wide, transverse band on posterior margin of each tergum; tergum 1 uniformly washed with dark brown, terga 2 and 3 washed with dark brown except anterolateral areas paler, terga 6-10 washed with dark brown similar to Figure 34; spiracles dark brown, tracheae washed lightly with dark brown. Genitalia (Figs. 24 and 25): brown, apical half of forceps paler; penes with small apical spines. Caudal filaments brown with darker brown annulations basally.

Male subimago. Unknown.

Female imago and subimago. Unknown.

Mature nymph (in alcohol). Head: blackish brown (Fig. 43), slightly paler posterior to lateral ocelli. Anteromedian margin of labrum straight, denticles weakly indicated (Fig. 48). Thorax: brown, venter paler, pronotum with lateral margins and submedian markings darker (Fig. 43), lateral areas of mesonotum and areas around forewing pads washed heavily with darker blackish brown, mesoscutum darker brown. Legs: pale; mid and hind coxae with brown macula; femora with dark brown macula distally and light brown mid-dorsal macula, macula faded on hind femora; apex of foretibiae dark brown; tarsi brown; outer margin of hind tibia with 15-27 spine-like setae. Abdomen: color and marks as in male imagos. Gills: membrane hyaline, tracheae black except at base. Caudal filaments brown.

Material. Holotype male imago, No. N53; paratypes: one nymph, No. N27; two males, No. N40; one male subimago, No. N42; two male subimagos, three nymphs, No. N51; nine nymphs, No. N52; five nymphs, No. N53; one nymph, No. N54; ten nymphs, No. N55; two nymphs, No. FNK9; three nymphs, No. FNK22; 15 nymphs, No. FNK23-24; five nymphs, No. FNK55; three nymphs, No. FNK 71; two nymphs, No. FNK 94. All types are in alcohol. Association of the nymphs and adults is by dissection of developing male genitalia from nymphs. Types are deposited in the following collections: holotype, one male, one male subimaginal and 17 nymphal paratypes at FAMU; one male, one male subimaginal and 16 nymphal paratypes at MZL; one male subimaginal and 16 nymphal paratypes at $\mathrm{NMNH}$; and 16 nymphal paratypes at BPBM. Additional specimens are recorded from localities N25 and FNK 10/13.

Etymology. Species is named for Barton A. Richard, Florida A\&M University, in recognition of his many contributions to the study of Ephemeroptera.

Diagnosis. Neampia (s.s.) richardi can be distinguished from the remaining species of Neampia (s.s.) by the following combination of characters. In the imago: (1) abdominal terga $1-3$ and $6-10$ of male are dark brown to brown and terga 4 and 5 are pale; and (2) apex of each penis lobe has a small apical spine (Figs. 24 and 25). In the nymph: (1) abdominal terga $1-3$ and 6-10 of male are dark brown and terga 4 and 5 are pale; (2) anteromedian margin of the labrum is straight with weakly indicated broadbased denticles (Fig. 48); (3) clypeus is blackish brown, and (4) posterior margin of hind tibia possesses 15-27 spine-like setae (similar to Fig. 68).

Discussion. The brown coloration on terga $2-4$ is more faded in the male from N40. The color pattern of male imagos is similar to that of $N$. inspina $n$. sp. from which it is distinguished by the presence of spines on the penes.

Biology. Neampia (s.s.) richardi was collected from small streams to large rivers on the East Coast and in the southern region at altitudes from 31 to $183 \mathrm{~m}$ and water temperatures of $19-24^{\circ} \mathrm{C}$ (most abundant at water temperatures of $19-20^{\circ} \mathrm{C}$ ). Subimagos were collected at light. Little is known about the biology of the species.

Goa, new subgenus (Figs. 1-4, 7-8, 11, 12, 14, 26-28, 36, $37,45,49,55-59,61,64,66,69$ and 71-74)

Diagnosis. Imago. Apex of each penis lobe of male genitalia with a large, apically curved spine; openings of penes at apex (Figs. 26-28, 71 and 72). Mature nymph. Dorsum of head and body somewhat cylindrical, venter flattened (Fig. 1). Mouthparts: anteromedian emargination of labrum concave; length of labrum about one-half width with broad-based denticles (Fig. 49); lateral margin of mandible relatively straight (Fig. 55). Prothorax rectangular, broader than head (Fig. 1). Legs: foretibiae flattened in cross-section (Fig. 64); femora flattened, ventrally concave and broadly expanded apically, paddlelike, especially fore and mid femora, so tibiae can draw completely underneath femora (Figs. 1, 61 and 64); outer margin of hind tibia with scattered spine-like setae (ca. 14-21), and long, fine setae about three times longer than spines. Small branches of median tracheae of gills present (Fig. 45) or absent basally. Posterolateral projections on abdominal segments 2 or 3-9.

Etymology. Goa, based on the name of the town Goa, New Caledonia. Feminine.

Type species. Neampia (Goa) natans new species.

Discussion. The characters listed above will distinguish the imagos and nymphs of Goa from those of Neampia (s.s.) and Anodela.

Neampia (Goa) natans, new species (Figs. 1-4, 7-8, $11,12,14,26-28,36,37,45,49,55-59,61,64,66,69$ and 71-74)

Male imago (in alcohol). Length: body $5.0-6.2 \mathrm{~mm}$, forewings 5.6-6.0 mm. Upper portion of eyes reddish brown, lower portion black (Figs. 7 and 8). Head brown, carinae darker, sutures paler. Antennal scape and pedicel dark brown, flagellum paler. Thorax dark brown, carinae darker, sutures paler, carinae of pleura and pronotum washed heavily with black. Coxae dark brown, remainder of legs pale, except apex of femora, foretibiae and tarsal segments 4 of mid and hind legs darker brown. Wings (Figs. 2-4): longitudinal veins of fore and hind wings brown, cross veins hyaline, except cross veins pale brown in apical fourth of cells $\mathrm{C}, \mathrm{Sc}$ and $\mathrm{R} 1$ of forewings; 
membrane of fore and hind wings hyaline, except base of fore and hind wings light brown, cells $\mathrm{C}$ and Sc of forewings translucent. Abdomen: light brown, terga 1-9 with dark brown, transverse band on posterior margin of each tergum, tergum 1 dark brown, terga 2 and 3 washed with dark brown (Fig. 37); terga 4 and 5 with paired, large, dark brown, sublateral bars on each tergum (Figs. 36 and 37), terga 6-10 washed with dark brown, tergum 8 paler; spiracles dark brown, tracheae washed lightly with dark brown, sternum 1 and sterna 6-9 uniformly washed with darker brown but sternum 6 lighter and with darker submedian oblique bars; ganglia washed lightly with darker brown. Genitalia (Figs. 26-28, 71 and 72): brown, styliger plate darker. Caudal filaments brown.

Male subimago. Markings as in male imago; wing membrane light brown.

Female imago (in alcohol). Length: body $5.5-6.3 \mathrm{~mm}$, forewings 7.0-7.1 mm. Eyes black. Head dark brown, carinae darker, sutures pale. Antennal scape and pedicel dark brown, flagellum lighter. Thorax: color and marks as in male imago. Coxae dark brown, remainder of legs brown to light brown, apex of femora dark brown, foretibiae with narrow, dark brown, transverse distal band, mid and hind tibiae darker at apex, foretarsi and tarsal segments 4 of mid and hind tarsi washed with dark brown. Wings: longitudinal veins of fore and hind wings dark brown, cross veins of fore and hind wings brown, except those in anterior half of forewings slightly darker, membrane of fore and hind wings light brown, except base of fore and hind wings darker, cells $\mathrm{C}$ and $\mathrm{Sc}$ of forewings translucent. Abdomen: color and marks as in male imago, except general color darker, sublateral bars on terga 4 and 5 larger, and sterna $2-9$ brown with lateral margins washed lightly with darker brown. Egg guide washed lightly with dark brown, posterior portion darker brown (Fig. 14). Caudal filaments pale.

Female subimago. As in female imago, except egg guide less developed and wing membrane light brown.

Mature nymph (in alcohol). Head: light brown, washed with darker brown anteriorly, between ocelli and on dorsum as in Figure 1. Thorax: dark brown, venter pale, pronotum pale with darker blackish-brown marks; lateral areas and posterior margin of forewing pads washed heavily with darker blackish brown (Fig. 1). Legs: pale, mid and hind coxae with dark brown macula, apex of femora dark brown, a larger dark brown, mid-dorsal macula on femora as in Figures 1 and 61, marks on tibiae as in male and female imagos, except darker, tarsi dark brown. Abdomen (Fig. 1): color and marks as in male and female imagos, except terga 8-10 paler, sterna uniformly pale except anterior margin of sterna 8 and 9 washed lightly with darker brown. Gills (Fig. 45): membrane hyaline, tracheae black. Caudal filaments pale.

Material. Holotype male imago, No. N37; allotype female imago, No. N37; paratypes: 205 nymphs, six males, seven male subimagos, eight females, 17 female subimagos, No. N37. All types are in alcohol. Association of the nymphs and adults is by rearing. All types are deposited in the following collections: holotype, allotype, three male, three male subimaginal, four female, nine female subimaginal and 80 nymphal paratypes at FAMU; two male, one male subimaginal, two female, three female subimaginal and 40 nymphal paratypes each at MZL and $\mathrm{NMNH}$; and one male, one male subimaginal, two female subimaginal and 40 nymphal paratypes at BPBM. Although types are restricted to specimens from N37, there are additional records from N19, N42, FNK37, FNK62 and FNK79. Other material has been collected by N. Mary at La Pouembout site $1\left(21.140^{\circ} \mathrm{S}, 165.122^{\circ} \mathrm{E}\right.$, $260 \mathrm{~m})$, 7-VIII-1977 and X-1976.

Etymology. natans, L., meaning swimming.

Diagnosis. Neampia (Goa) natans sp. n. is the only species known in this subgenus and is recognized by distinctive characters of the subgenus.

Discussion. Males are generally smaller than females. The color pattern is less intense in some specimens and leg markings are darker and more pronounced in females.

Biology. Neampia (Goa) natans has been collected from a few mountain streams along the East Coast but most were found at one undisturbed site at a higher altitude $(458 \mathrm{~m})$. Water temperatures were $18-19{ }^{\circ} \mathrm{C}$ when collected $\left(15.2^{\circ} \mathrm{C}\right.$ at FNK 79). Nymphs were excellent swimmers. They were found in still pools along the banks and at the bottom of waterfalls resting on rocks, but when disturbed they swam quickly to another part of the pool (usually under edges of rocks). As quick, darting swimmers, their behavior resembles that of members of the Baetidae.

Nymphs apparently prefer very clean water. Where a dirt road forded the stream (locality No. N37), nymphs were observed above but not below the ford although there was only a slight increase of silt. Most other species occurred both above and below the ford.

Subimagos emerged from 1500 to $1900 \mathrm{~h}$ with most emerging before sunset $(1800 \mathrm{~h})$. Imagos molted the next morning. Swarming was not observed, and no specimens were collected at light.

Anodela, new subgenus (Figs. 6, 10, 15, 29-33, 38-42, 50, 54, 62 and 70)

Diagnosis: Imagos. Apex of each penis lobe of male genitalia with strong apical spines (Figs. 29-33); openings of penes subapical. Mature nymph. Head and body flattened dorsoventrally (Fig. 42). Mouthparts: anteromedian emargination of labrum nearly straight to shallowly curved ventrally; length of labrum along median line one-third maximum width (Fig. 50); outer margin of mandible curved, with depression anterior to lateral setal tuft (Fig. 54). Foretibiae oval in cross section; outer margin of femora indented so tibiae can draw partially into femora (Fig. 62). Hind tibiae with few (3-6) heavy spine-like setae (Fig. 70). Posterolateral spines on abdominal segments 2 or $3-9$.

Etymology. Anodela, an arbitrary combination of letters, partially based on anagram of Caledonia.

Type species. Neampia (Anodela) fluvialis, new species.

Discussion. The characters above will distinguish the imagos and nymphs of Anodela from those of Neampia (s.s.) and Goa. A few other unassociated nymphs of Neampia (Anodela) collected at various localities in the 
southern region and along the West Coast are not assigned to species.

Neampia (Anodela) fluvialis, new species (Figs. 10, 29-32, 38-40, 42, 50, 54, 62 and 70)

Male imago (in alcohol). Length: body $3.2-4.2 \mathrm{~mm}$; forewings 4.1-4.4 $\mathrm{mm}$. Upper portion of eyes reddish brown, lower portion black. Head dark brown, carinae darker. Antennal scape and pedicel dark brown, flagellum much paler. Prothorax blackish brown, mesothorax dark brown, carinae darker, sutures paler, carinae surrounding bases of legs and wings washed heavily with blackish brown. Coxae blackish brown; forefemora and foretibiae light brown with apex much darker, remainder of forelegs pale; mid and hind legs pale brown, apex of tibiae washed with blackish brown. Wings: longitudinal veins of fore and hind wings light brown; membrane hyaline, except base of wings light brown; apical third of cells $\mathrm{C}$ and Sc of forewings translucent. Abdomen: dark brown, terga 1-8 heavily washed with dark blackish brown (Figs. 38 and 40), terga 9-10 washed with lighter brown, terga $2-9$ with narrow, pale, median longitudinal line extended entire length of each tergum, dark blackish brown lateral and sublateral marks on terga as in Figure 39; spiracles dark blackish brown, tracheae washed with light brown; posterolateral corners of sterna 2-9 with large, darker brown maculae, maculae faded on sterna 5-8. Genitalia (Figs. 29-32): brown, apical half of forceps paler. Caudal filaments pale with dark annulations at articulations.

Male subimago (in alcohol). As in male imago, except for usual developmental differences; wing membrane grayish tan.

Female imago (in alcohol). Length: body $5.5 \mathrm{~mm}$; forewings $5.5 \mathrm{~mm}$. Color and markings as in male imago, except mesothorax lighter brown. Margin of sternum 7 pale, anterior margin of sternum 8 shaded dark gray.

Female subimago (in alcohol). Color and markings as in male imago; wing membrane grayish tan; egg guide weakly indicated, not extended as in imagos.

Mature nymph (in alcohol). Head: brown, venter lighter, dorsum washed heavily with darker blackish brown between eyes and ocelli (Fig. 42), clypeus pale. Thorax: dark brown, venter lighter, lateral area of mesonotum and areas around forewing pads washed heavily with dark blackish brown, pronotum with broad, blackish-brown median macula as in Figure 42. Legs: light brown; mid and hind coxae with dark brown macula; femora washed lightly with dark brown, darker apically, tarsi reddish brown (Fig. 62). Abdomen: color and marks as in male imago, except median longitudinal line on terga light brown. Gills (Fig. 42): membrane gray, tracheae black. Caudal filaments brown.

Material. Holotype male imago, No. N50; allotype female imago, No. N51; paratypes: one nymph, one male subimago, No. N25; three males, No. N50; 49 nymphs, four male subimagos, one female subimago, No. N51; two males, No. N53, five nymphs, No. FNK 23-24. All types are in alcohol. Association of the nymphs and adults is by rearing. Types are deposited in the following collections: holotype, allotype, two male, two male subimaginal and
22 nymphal paratypes at FAMU; three male, two male subimaginal, one female subimaginal and 15 nymphal paratypes at MZL, one male subimaginal and nine nymphal paratypes each at NMNH and BPBM.

Etymology. fluvialis, L., referring to a river, in this case the type locality Rivière Bleue.

Diagnosis. Neampia (Anodela) fluvialis can be distinguished from the other species of Neampia (Anodela) by the following combination of characters. In the imago: abdominal terga $1-10$ of the male are dark brown and heavily washed with blackish brown (Figs. 38 and 40), and (2) apex of each penis lobe of male genitalia has a strong, ventral spine (Figs. 29-31). The same color pattern applies to the nymphs: (1) abdominal terga 1-10 are dark brown (Fig. 42).

Discussion. There are several small population variations not included in the type series; these might eventually represent additional species or subspecies but are here treated as variations of $N$. (A.) fluvialis. In imagos from the paratype series, tergum 5 is either dark brown (as the rest of terga) or possesses a median macula only a shade grayer than that on other terga (Fig. 40), and femora are light brown basally and darker apically. Variations include:

1. Femora blackish (two nymphs, N25; two male imagos and one male subimago, N53).

2. Posterior portion of tergum 5 pale without blackish submedian longitudinal line (nymphs only, N27, N55).

3. Three nymphs from N37 seem to have the color pattern of $N$. (A.) fluvialis, but all other specimens from these localities belong to $N$. (A.) septentrionalis n. sp. In the absence of male imagos, these specimens are treated here as a variant.

Biology. The type series of Neampia (Anodela) fluvialis was found in the southern region and in medium to largesized rivers. Nymphs were found in streams with water temperatures of $19-20.5^{\circ} \mathrm{C}$ at elevations from 150 to 183 $\mathrm{m}$. The species was most abundant around the Rivière Bleue. Nymphs were collected under small rocks along the river bank in slow moving water. Subimagos were collected at light, but swarming was never seen.

Neampia (Anodela) septentrionalis, new species (Figs. 6, 15, 33 and 41)

Male imago (in alcohol). Length: body, $4.5 \mathrm{~mm}$; forewings, $4.5 \mathrm{~mm}$. Upper portion of eyes reddish brown, lower portion black. Head dark brown, carinae darker. Antennal scape and pedicel dark brown, flagellum much paler. Thorax dark brown, carinae darker, sutures paler, carinae around bases of legs and wings washed heavily with darker brown, margins and carinae of pronotum washed heavily with darker brown. Coxae dark brown, remainder of legs pale, except forefemora slightly darker, apex of femora and tibiae dark brown. Wings: longitudinal veins of fore and hind wings light brown, cross veins hyaline except those in cells $\mathrm{C}$ of forewings pale brown; membrane hyaline, apical third of cells $\mathrm{C}$ and $\mathrm{Sc}$ of forewings translucent. Abdomen: light brown, terga 1-10 
washed with blackish brown except for large pale macula on tergum 5, terga 6-10 darker brown, terga 1-10 with narrow, pale, median longitudinal line extended entire length of each tergum (Fig. 41) and with paired pale sublateral triangular-shaped marks next to submedian blackish lines on terga 2-8 (Fig. 41); spiracles dark brown, tracheae hyaline; sterna 8 and 9 uniformly washed with darker brown. Genitalia and caudal filaments broken off and missing.

Male subimago (in alcohol). As in male imago, except for usual developmental differences; wing membrane light brown. Genitalia as in Figure 33.

Female imago (in alcohol). Length: body $4.0-4.8 \mathrm{~mm}$; forewings $5.2-5.5 \mathrm{~mm}$. Eyes black. Head brown, area between eyes and ocelli darker. Antennal scape and pedicel brown, flagellum paler. Thorax: color and marks as in male imago. Wings: longitudinal veins in fore and hind wings brown, cross veins light brown, except faded in posterior half of wings; membrane of fore and hind wings hyaline to light brown, except base of wings darker, apical third of cells $\mathrm{C}$ and $\mathrm{Sc}$ of forewings translucent. Color and marks of legs as in male imago, except tarsi washed lightly with darker brown. Abdomen: color and marks as in male imago, except pale submedian marks on terga absent, lateral margins of sterna 1-7 washed lightly with darker brown. Egg guide as in Figure 15. Caudal filaments brown.

Mature nymph (in alcohol). Head: brown, venter lighter, dorsum washed heavily with darker brown between eyes and ocelli. Thorax: dark brown, venter lighter, lateral areas of mesonotum and areas around forewing pads washed heavily with darker brown. Pronotum with darker brown median macula similar to that in Figure 42. Legs: pale, mid and hind coxae with brown maculae, other color and marks as in male and female imagos, except tarsi reddish brown. Abdomen: color and marks as in imagos. Gills: membrane gray, tracheae blackish gray. Caudal filaments brown.

Material. Holotype male subimago, No. N42; allotype female imago, No. N37; paratypes: two nymphs, one male, three females, No. N37; four nymphs, No. N42; one nymph, No. N44; one nymph, No. FNK42; one nymph, No. FNK53; two nymphs, No. FNK79; one nymph, No. FNK86; six nymphs, No. FNK95; three nymphs, No. FNK121. Association of the nymphs and adults is by rearing. Types are deposited in the following collections: holotype, allotype, one male, one female and seven nymphal paratypes at FAMU; one female and six nymphal paratypes at MZL; one female and four nymphal paratypes at NMNH; and four nymphal paratypes at BPBM.

Etymology. septentrionalis, L. meaning north.

Diagnosis. Neampia (Anodela) septentrionalis can be distinguished from the other species of Neampia (Anodela) by the following combination of characters. In the imago: abdominal terga 1-10 of male are brown, heavily washed with dark blackish brown and with a large pale macula on tergum 5 (Fig. 41). The same color pattern character applies to nymphs: (1) abdominal terga 1-10 dark brown with a large pale macula on tergum 5 .
Discussion. The intensity of the coloration on the egg guide is pale in some specimens.

Biology. Neampia (Anodela) septentrionalis occurs along the East Coast and is found in small to large streams. Nymphs were collected in streams with water temperatures of $15-20{ }^{\circ} \mathrm{C}$ and elevations of about $20-458 \mathrm{~m}$.

Acknowledgements. Field work for this study was supported by the National Geographic Society, Washington, D.C., under a grant to William L. Peters. Some laboratory research was supported by a research program of the Scientific and Educational Administration, CSREES, United States Department of Agriculture. We thank Dr. David R. Towns (Auckland) for scanning electron microscope photographs Figures 71 and 72 and Ms. Lachanda Mitchell (Orlando) for Figures 73 and 74. Dr. William L. Peters is acknowledged for initiating the research and preparing original drafts of this manuscript. We also acknowledge the efforts of Dr. Michael D. Hubbard who made great contributions toward its completion. Finally, we thank the reviewers for the journal whose comments and suggestions greatly improved the final manuscript.

\section{References}

Mary N. and Archaimbault V., 2012. Amélioration des méthodes indicielles Indice Biotique de la Nouvelle-Calédonie (IBNC) et Indice Bio-sédimentaire (IBS). Phase 2. Rapport ETHYC'O et IRSTEA. Observatoire de l'environnement en Nouvelle-Calédonie, 75 p.

Peters W.L. and Peters J.G., 1980. The Leptophlebiidae of New Caledonia (Ephemeroptera). Part II. - systematics. Cah. ORSTOM Hydrobiol., 13, 61-82.

Peters W.L. and Peters J.G., 1981a. The Leptophlebiidae: Atalophlebiinae of New Caledonia (Ephemeroptera). Part III. - systematics. Rev. Hydrobiol. Trop, 14, 223-243.

Peters W.L. and Peters J.G., 1981b. The Leptophlebiidae: Atalophlebiinae of New Caledonia (Ephemeroptera). Part IV. - systematics. Rev. Hydrobiol. Trop., 14, 245-252.

Peters W.L. and Peters J.G., 2000. The Leptophlebiidae: Atalophlebiinae of New Caledonia (Ephemeroptera): part VII: systematics. Ann. Limnol. - Int. J. Lim., 36, 31-55.

Peters W.L., Peters J.G. and Edmunds G.F. Jr., 1978. The Leptophlebiidae of New Caledonia (Ephemeroptera). Part I. - introduction and systematics. Cah. ORSTOM Hydrobiol., 12, 97-117.

Peters W.L., Peters J.G. and Edmunds G.F. Jr., 1990. The Leptophlebiidae: Atalophlebiinae of New Caledonia (Ephemeroptera). Part V. - systematics. Rev. Hydrobiol. Trop., 23, 121-140.

Peters W.L., Peters J.G. and Edmunds G.F. Jr., 1994. The Leptophlebiidae: Atalophlebiinae of New Caledonia (Ephemeroptera). Part VI. - systematics. Rev. Hydrobiol. Trop., 27, 97-105.

Starmühlner F., 1968. Études hydrobiologiques en NouvelleCalédonie (Mission 1965 du Premier Institut de Zoologie de l'Université de Vienne). 1. Généralités et description des stations. Cah. ORSTOM Hydrobiol., 2, 3-33.

Towns D.R. and Peters W.L., 1996. Fauna of New Zealand: Leptophlebiidae (Insecta: Ephemeroptera). Fauna New Zealand, 36, $144 \mathrm{p}$. 


\section{Appendix}

Table A1. Locality codes for material cited in this paper (prefix N from Peters et al., 1978, collectors W.L. \& J.G. Peters, W.M. Beck, Jr., G.F. Edmunds, Jr.); prefix FNK from Starmühlner, 1968, collectors F. Starmühlner, E. Oberzeller, A. Kaltenbach).

\begin{tabular}{|c|c|}
\hline N13 & Nondoué Riv., 12 km NW of Dumbéa. 6.IX.1972 \\
\hline N14 & Stream, Val d'Hermitage. 7.IX.1972 \\
\hline N15 & Tributary of Karionan Riv., 5 km NNW of Païta. 10.IX.1972 \\
\hline N19 & Ba Quinoré Riv., 3 km NE of Col d'Amieu Forest on Terr. Route 5. 15.IX.1972 \\
\hline N21 & Stream on Eaux et Forêts road, NW of Col d'Amieu. 16.IX.1972 \\
\hline $\mathrm{N} 25$ & $\begin{array}{l}\text { Stream on Mt. Pouédihi, Bon Secours, } 7 \text { km NW of Ouénarou Forest Station on Eaux et Forêts road. } \\
\text { 22.IX.1972 }\end{array}$ \\
\hline $\mathrm{N} 27$ & Stream on Pic Mouirange, Camp des Travaux Publics on Terr. Route 2. 24/29.IX.1972 \\
\hline N34 & Stream, Val d’Hermitage. 10.X.1972 \\
\hline N35 & Tributary of Karionan Riv., 5 km NNW of Païta. 11/12.X.1972 \\
\hline N37 & Stream on Mt. Aoupinié, on Goa road 22 km SW of bridge at Ponérihouen. 17/21.X.1972 \\
\hline N40 & Nérihouen Riv., Goa, 13.5 km SW of bridge at Ponérihouen. 18/20.X.1972 \\
\hline N41 & Poema Riv., Station Castex, Kavatch-Hienghène Forest Station. 22/29.X.1972 \\
\hline N42 & Stream on Mt. Gaata, 4.3 km NW of Station Castex. 23/29.1972 \\
\hline N44 & Stream below Cascade de Ouaïna, Cap Colnett, 1.4 km NW of Galarino. 27.X.1972 \\
\hline N46 & Stream on Eaux et Forêts road, NW of Col d'Amieu. 31.X.1972 \\
\hline N50 & Stream on Mt. Pouédihi, 15 km W of Ouénarou Forest Station on Eaux et Forêts road. 5.XI.1972 \\
\hline N51 & Riv. Bleue at bridge on Eaux et Forêts road, 21 km NW of Ouénarou Forest Station. 6.XI.1972 \\
\hline N52 & $\begin{array}{l}\text { Stream on Mt. Pouédihi, Bon Secours, } 7 \text { km NW of Ouénarou Forest Station on Eaux et Forêts road. } \\
\text { 8/10.XI.1972 }\end{array}$ \\
\hline N53 & Stream on Mt. Pouédihi, 16.5 km W of Ouénarou Forest Station on Eaux et Forêts road. 8/10.XI.1972 \\
\hline N54 & Tributary of Karionan Riv., 5 km NNW of Païta. 14.XI.1972 \\
\hline FNK4 & $\begin{array}{l}\text { Affluent de la Rivière Dumbéa, affluent de gauche, entre FNK16 et } 14.9 \text { km en aval du barrage. } \\
\text { 11.VII.1965 }\end{array}$ \\
\hline FNK5 & Rivière Dumbéa: branche sud de la Dumbéa, $5 \mathrm{~km}$ en aval du barrage, près de Koué. 12.VII.1965 \\
\hline FNK9 & Affluents de la rivière Dumbéa, affluent de droite, $1 \mathrm{~km}$ en aval du barrage. 3.IX.1965 \\
\hline FNK10/13 & Affluent de la Rivière Dumbéa, 3 km en aval du barrage, près de la route. 15.VII.1965. \\
\hline FNK22 & $\begin{array}{l}\text { Affluent de droite de la rivière Pirogue près de la route Nouméa-Yaté, } 5 \mathrm{~km} \text { avant la station forestière de } \\
\text { Ouénarou. 20.VII.1965 }\end{array}$ \\
\hline FNK23/24 & Rivière Bleue près du pont. 21.VII.1965 \\
\hline FNK37 & Rivière Ouen Koh, cours supérieur près de la station forestière du col d'Amieu. 26.VII.1962 \\
\hline FNK42 & Rivière Tindia, affluent de La Farino au nord-ouest du village de Farino. 28.VII.1962 \\
\hline FNK47 & $\begin{array}{l}\text { Ruisseau thermal près La Crouen: écoulement, du bassin de la source thermale. Un ruisseau froid se jette } \\
\text { dans l'écoulement de la source thermale. 29.VII.1965 }\end{array}$ \\
\hline FNK52 & Rivière Sarraméa, cours supérieur au pied du mont Dogny, prés Sarraméa. 30.VII.1965 \\
\hline FNK53 & Rivière Ouen Koh, zone des cascades, $50 \mathrm{~m}$ en aval de FNK 37. 30.VII.1965 \\
\hline FNK55 & Rivière La Coulée, cours supérieur, 20 km en amont de l'embouchure, a l'est de Saint Louis. 4.VIII.1965 \\
\hline FNK62 & Rivière Nekliai 5 km en amont de la Mission oat,holique de Nekliai. 10.VIII.1965 \\
\hline FNK66 & $\begin{array}{l}\text { Cours supérieur de la rivière Poya, dans la gorge de Ndokoa, entre le pic Adio et la dent de Poya. } \\
\text { 12.VIII.1965 }\end{array}$ \\
\hline FNK71 & $\begin{array}{l}\text { Rivière des Lacs s'écoulant du Lac en Huit dans la Plaine des Lacs, près de la route de Nouméa. } \\
\text { 17.VIII.1965 }\end{array}$ \\
\hline FNK79 & $\begin{array}{l}\text { Ruisseau Ouarau, aflluent de gauche du cours supérieur de la rivière Tchamba, près de la ferme Letocart, } \\
\text { au nord du village de Tchamba. 25.VIII.1965 }\end{array}$ \\
\hline FNK86 & $\begin{array}{l}\text { Rivière Pouboui, affluent de droite près du village de Néavin, } 8 \mathrm{~km} \text { en amont de l'embouchure du Néavin. } \\
\text { 29.VIII.1965 }\end{array}$ \\
\hline FNK94 & Rivière Hienghène, cours supérieur prés Kavatch. 6.IX.1965 \\
\hline FNK95 & $\begin{array}{l}\text { Affluent de gauche de la riviere Hienghène, } 5 \mathrm{~km} \text { en aval de FNK 94, près de la st,ation } \\
\text { Castex. 6.IX.1965 }\end{array}$ \\
\hline FNK105 & Cours moyen du Rivière Diahot, près du village d’Ouénia (chapelle de Saint-Joseph). 16.IX.1965 \\
\hline FNK121 & Rivière Tioli, affluent de la riviére Ouen Koh, au pied du mont Table Unio. 27.IX.1965 \\
\hline
\end{tabular}


Table A2. Source of material for figures.

\begin{tabular}{|c|c|c|}
\hline Species & Figure numbers & Locality \\
\hline \multirow{5}{*}{ Neampia s.s. quaternaria } & $35,44,60,63,67$ & N21 \\
\hline & 5,18 & N35 \\
\hline & $17,19,34$ & N50 \\
\hline & 9,20 & N53 \\
\hline & $46,51-52,65$ & N54 \\
\hline \multirow[t]{2}{*}{ Neampia s.s. inspina } & 23 & N35 \\
\hline & $21-22,47,68$ & N54 \\
\hline \multirow[t]{2}{*}{ Neampia s.s. richardi } & $24-25$ & N40 \\
\hline & $43,48,53$ & N52 \\
\hline Neampia $($ Goa $)$ natans & All figures & N37 \\
\hline \multirow[t]{5}{*}{ Neampia (Anodela) fluvialis } & $6,10,29-31$ & N53 \\
\hline & 42 & N52 \\
\hline & $32,50,54,62,70$ & N51 \\
\hline & $38-39$ & N50 \\
\hline & 40 & N27 \\
\hline Neampia $($ Anodela $)$ & 33 & N42 \\
\hline septentrionalis & 15,41 & N37 \\
\hline Neampia sp. female & 13,16 & N54 \\
\hline
\end{tabular}

